\title{
Two Great Transfers of Word Emotive Overtones In Modern Chinese
}

\author{
Diao Yanbin* Ye Jiaquan ${ }^{* *}$
}

\begin{abstract}
Since 1949, modern Chinese language has, in the course of its development in Mainland China, twice witnessed large-scale transfers in its word emotive overtones. The first began in 1949 and went on all the way till the end of the Cultural Revolution in 1977. Derogation manifested itself in that period, during which the derogatory words enjoyed their greatest number, widest usages and highest frequency in the history of the Chinese language. The second began from the Reform and Opening Up Policy in 1978 and lasted untill now. De-derogation has manifested itself in this period, during which the derogatory words have had the smallest number, least usages and lowest frequency in the history of the Chinese language. The two large-scale transfers result from their specific social backgrounds and the development of the Chinese language itself.
\end{abstract}

Key words: Modern Chinese language, emotive overtones, transfers

\section{Introduction}

Word emotive overtone, commendatory and derogatory, is very important and common among its types of meanings, and co-varies closely with social life and language psychology. It reflects our common emotional standards on the true, the good and the beautiful, the false, the bad and the ugly and the ethical judgment, which have already been established in the history of mankind, onto word meanings. Therefore, emotive overtone is part of the sociality and stability of word meanings. However, social development and progress of the times and knowledge can make subjects change their emotional standards on judging their objects, which means some changes will take place in word emotive overtones in the course of their development (Yang Zhenlan, 2003:169).

Though it is undeniable that there can be changes in word emotive overtones, it is believed that such changes take time and come very slowly (Zhang Zhen'an, 2005), which

\footnotetext{
* Diao Yanbin: Department of Chinese Language and Literature, Beijing Normal University, Beijing City, 100875, Email: diaoyanbin@sina.com, diaoyanbin@yahoo.com.cn.

** Ye Jiaquan: Nanjing University of Finance and Economics, No. 3, Wenyuanlu Road, Yadong New Town, Nanjing City, 210046, Email: yejiaquan@126.com.
} 
does not go along with our facts. We find that in a very short period of time (less than 90 years from the May Fourth Movement, in 1919), Modern Chinese language has twice witnessed large-scale transfers in its word emotive overtones in the direction of amelioration or derogation. One began in 1949 and went on all the way till the end of the Cultural Revolution in 1977 (the Cultural Revolution began in 1966). Derogation manifested itself in that period, during which the derogatory words enjoyed their greatest number, widest usage and highest frequency in the history of the Chinese language. The other began from the Reform and Opening Up Policy in 1978 and lasted untill now. De-derogation has manifested itself in this period, during which the derogatory words have had the smallest number, least usage and lowest frequency in the history of the Chinese language. The two large-scale transfers result from their specific social backgrounds and the development of the Chinese language itself. Study and analysis of the very unique phenomenon are of great importance to mastery of the rules of word meaning changes.

\section{The first large-scale transfer}

It can simply be referred to as Derogation. Taking political and other factors into account, the derogation phenomenon of the modern Chinese language can be traced back to 1949, prior to the foundation of the People's Republic of China, when China was in war. The large-scale derogation began after 1949 and reached its peak during the Cultural Revolution, finally resulting in the first large-scale transfer of the Chinese semantic emotive overtones.

Derogatory terms refer to those used to deny or denounce something, sometimes called repugnant words. To be more specific, derogatory terms are all those emotive-colored words meant to denounce, vilipend, criticize, sneer, revolt, discriminate and to be ugly and dangerous (Xing Gongwan, 1994; Yang Ling \& Zhu Yinggui, 2005). During the Cultural Revolution Chinese language featured out-of-range and excessive uses of derogatory terms, a trend of derogation resulting from language violence background. Cruel struggle and ruthless blows were typical of the political movement in the Cultural Revolution. As a consequence, language violence was abused as a weapon to launch personal attack, persecution and ravage. During this period a large number of popular terms smelled bloody, a lingering fear even today. Those special violent terms were excessively abused on any occasion and objects, for the sake of attack, curse and denouncement.

A. Attacking Language Attacking language, including some generalized military terms, is often used as a one-stone-kills-two-birds strategy. On the one hand, its user can give vent to his/her indignation. On the other hand, the user is trying to deter his/her rival. 
Therefore, terms of this kind were frequently used during the Cultural Revolution. Verbs have selective emotive overtones for their objects (Yuan Yulin, 1987), and therefore attacking language is mostly verbs in derogatory sense toward recipients. We chose some frequently used attacking verbs and studied their uses in different years with the help of the People's Daily Database of Texts and Pictures (1946-2005) from which the data in Tables 1 to 4 was derrived. The statistics show that those verbs were used most frequently in 1967 during the Cultural Revolution. The following table shows the frequency of the four of the attacking vocabulary, “dădăo (打倒, to down with), dăsuì (打碎, to break up), héngsăo (横 扫, to sweep away), pàodă (炮打, to bombard)”, reaching their peak values during this period.

Table 1 Statistical table of attacking vocabulary

\begin{tabular}{|c|c|c|c|c|c|c|c|c|}
\hline \multirow{2}{*}{$\begin{array}{l}\text { Attacking } \\
\text { terms }\end{array}$} & \multicolumn{2}{|c|}{$\begin{array}{l}\text { dădăo (打倒, } \\
\text { to down with) }\end{array}$} & \multicolumn{2}{|c|}{$\begin{array}{l}\text { dăsuì (打碎, } \\
\text { to break up) }\end{array}$} & \multicolumn{2}{|c|}{$\begin{array}{l}\text { héngsăo (横扫, } \\
\text { to sweep away) }\end{array}$} & \multicolumn{2}{|c|}{$\begin{array}{l}\text { pàodă (炮打, } \\
\text { to bombard) }\end{array}$} \\
\hline & Samples & Frequency & Samples & Frequency & Samples & Frequency & Samples & Frequency \\
\hline 1947 & 288 & 28.8 & 16 & 1.6 & 73 & 7.3 & 16 & 1.6 \\
\hline 1957 & 197 & 9.85 & 37 & 1.85 & 8 & 0.4 & 5 & 0.25 \\
\hline 1967 & 1258 & 83.87 & 112 & 7.47 & 107 & 7.13 & 86 & 5.73 \\
\hline 1977 & 804 & 53.6 & 27 & 1.8 & 22 & 1.47 & 10 & 0.67 \\
\hline 1987 & 57 & 2.85 & 22 & 1.1 & 16 & 0.8 & 2 & 0.05 \\
\hline 2005 & 59 & 1.48 & 9 & 0.23 & 29 & 0.73 & 5 & 0.13 \\
\hline
\end{tabular}

(Note: the frequency here means occurrences per million words, e.g. 28.8 means 28.8 occurrences per million words. The same is true in the following tables)

B. Cursing Language Cursing language refers to the terms used to curse somebody, insolent or venomous language to insult somebody. Cursing language is a hot topic in theses on the Cultural Revolution language, "de-personification is often adopted in cursing language to dehumanize somebody as something disgusting, aimed to vilify, vilipend, attack and to give vent. For example, 'gǒuzăizi (狗㩄子, feist)', 'biànsèlóng (变色龙, chameleon)', 'xiăo páchóng (小爬虫, reptilian)', 'hēi gēnzi (黑根子, black root)', 'shuāngliàohuò (双料货, double agent)', 'tǔwéizi (土围子, earth fence)', 'niúguǐ-shéshén (牛鬼蛇神, evil people of all kinds)', 'cánzhā yúniè (残渣余蕉, remnants of the enemy force)', and 'dìngshí zhàdàn (定时炸弹, time bomb)'. Other cursing terms such as 'huánxiāngtuán (还乡团, returning enemies to counterattack)', 'chuīgǔshǒu (吹鼓手, advocator of a particular counter-revolutionary theory)' are often used in a derogatory sense." (Zhou Jian \& Li Genxiao, 1998) Cursing terms collected in the Contemporary Chinese Dictionary and labeled "taboo", such as "gŭndàn (滚蛋, fuck off)", "guǐ (鬼, ghost)”, “hún dàn (浑蛋/混蛋, bastard)”, “huàidàn (坏蛋, wretch)”, “zázhǒng (杂种, 
mongrel)", reached their peak frequency during the Cultural Revolution, unparalleled before and after that. The following table well shows us that.

Table 2 Statistical table of curses

\begin{tabular}{|c|c|c|c|c|c|c|c|c|}
\hline \multirow{2}{*}{$\begin{array}{c}\text { Cursing } \\
\text { terms }\end{array}$} & \multicolumn{2}{|c|}{ gǔndàn (滚蛋, fuck off) } & \multicolumn{2}{|c|}{ guǐ (鬼, ghost) } & \multicolumn{4}{|c|}{ húndàn (浑蛋/混蛋, bastard huàidàn (坏蛋, wretch) } \\
\hline & Samples & Frequency & Samples & Frequency & Samples & Frequency & Samples & Frequency \\
\hline 1947 & 22 & 2.2 & 97 & 9.7 & 14 & 1.4 & 139 & 13.9 \\
\hline 1957 & 14 & 0.7 & 127 & 6.35 & 10 & 0.5 & 19 & 0.95 \\
\hline 1967 & 28 & 1.87 & 160 & 10.67 & 70 & 4.67 & 68 & 4.53 \\
\hline 1977 & 7 & 0.47 & 69 & 4.6 & 0 & 0 & 23 & 1.53 \\
\hline 1987 & 1 & 0.05 & 80 & 4 & 0 & 0 & 4 & 0.2 \\
\hline 2005 & 2 & 0.2 & 62 & 1.55 & 0 & 0 & 2 & 0.2 \\
\hline
\end{tabular}

C. Derogatory Language Derogatory language lays emphasis on critical and snubbing comments and statements, while cursing language mainly expresses the subject's disparaging attitude toward the object. Of course, they are different in force and form. Some derogatory terms, including derogatory adjectives such as "āngzāng (肮脏, filthy)", “bēibǐ (卑鄙, despicable)”, “chāngkuáng (猖狂, savage)”, “chǒu’è (丑恶, hideous)”, and derogatory verbs such as "băchí (把持, to monopolize)", "bāobì (包庇, to enshield)", "bèipàn (背叛, to betray)", "bèilí (背离, to deviate)", "biāobăng (标榜, to hold up oneself)", "cuànduó (篹夺, to usurp)", and derogatory adverbs, for example "dàsì (大肆, wantonly)" and derogatory nouns such as "dăngyǔ (党羽, henchman)", “guǐ-băxì (鬼把戏, mockery)” and derogatory idioms such as "shí’è-bùshè (十恶不政, unpardonably wicked)", “dàchuī-dàléi (大吹大擂, to bluff and bluster)", “dàfàng-juécí (大放厥词, to talk a lot of nonsense)”, “dàyán-bùcán (大言不惭, to brag unblushingly)”, “kǒushì-xīnfēi (口是心非, to say one thing and mean another)", are often used to denounce. The following statistics covers the uses of such terms in different years and shows their peak frequency during the Cultural Revolution.

Table 3 Statistical table derogatory language

\begin{tabular}{|c|c|c|c|c|c|c|c|c|}
\hline \multirow[t]{2}{*}{ Terms } & \multicolumn{2}{|c|}{$\begin{array}{l}\text { dàsì (大肆, } \\
\text { wantonly) }\end{array}$} & \multicolumn{2}{|c|}{$\begin{array}{l}\text { fǔxiǔ (腐朽, } \\
\text { rotten) }\end{array}$} & \multicolumn{2}{|c|}{$\begin{array}{l}\text { míngmù-zhāngdăn } \\
\text { (明目张胆, brazenly) }\end{array}$} & \multicolumn{2}{|c|}{$\begin{array}{l}\text { lăngbèi-wéijiān (狼狈 } \\
\text { 为奸, in collusion with) }\end{array}$} \\
\hline & samples & frequency & samples & frequency & samples & frequency & samples & frequency \\
\hline 1947 & 168 & 16.8 & 13 & 1.3 & 15 & 1.5 & 16 & 1.6 \\
\hline 1957 & 347 & 17.35 & 179 & 8.95 & 92 & 4.6 & 15 & 0.75 \\
\hline 1967 & 696 & 46.4 & 255 & 15 & 245 & 16.33 & 100 & 6.67 \\
\hline 1977 & 370 & 24.67 & 114 & 7.6 & 150 & 10 & 33 & 2.2 \\
\hline 1987 & 79 & 3.95 & 127 & 6.35 & 34 & 1.7 & 2 & 0.1 \\
\hline 2005 & 104 & 2.6 & 57 & 1.43 & 21 & 0.53 & 2 & 0.05 \\
\hline
\end{tabular}


Language derogation during the Cultural Revolution consists of three obvious aspects:

(a) Quite a lot of commendatory and neutral lexical entries are completely or partly derogated. This happened after the liberation, especially during the Cultural Revolution. Among the neutral-to-derogatory transfers are, for example, "biāoběn (标本, specimen, sample)”, “dùjīn (镀金, gild)”, “fānbăn (翻版, republication, copy)”, and terms like “làngmàn (浪漫, romantic)”, “qiánchéng (虔诚, devout)”, “qīnggāo (清高, chastely, high-heartedly)" and "cíbēi (慈悲, mercy)" are some of the commendatory-to-derogatory transfers. Four types of such transfers can be easily observed. The first are applied to human beings such as "dìwáng (帝王, Emperor, king)", "shèngrén (圣人, Saint)", “dìzhŭ (地主, landlord)”, “gōngž̃ (公子, childe)”, “shàoye (少爷, signorino, young master)”, “xiăojiě (小姐, miss, young female master)”, “zīběnjiā (资本家, capitalist)”, “guìzú (贵族, lord, nobleman)", "qíngrén (情人, lover)”, and "quánwēi (权威, authority)”; the second are applied to objects such as “àiqíng (爱情, love)”, “qínggē (情歌, love song)”, “bó’ài (博爱, philanthropy)", “biànzhǒng (变种, variation)", “gèrén zhǔyì (个人主义, individualism)”, “jiăngjīn (奖金, award money, bonus)”, “căilǐ (彩礼, betrothal gifts)”, “wàikuài (外快, extra income)”, “jǔnbiāo (锦标, trophy)” and “jítuán (集团, group)”, and the third of the transfers refer to the quality or state, such as "ānlè (安乐, peace or/and happiness)", "fùguì (富贵, riches and honor)”, “fùyù (富裕, wealthy)”, “háohuá (豪华, luxurious)”, “làngmàn (浪漫, romantic)”, “jiāoguì (娇贵, delicate)”, “cíbēi (慈悲, mercy)”, “císhàn (慈善, charity)", “rényì (仁义, humaneness)" and "gūgāo (孤高, cold-and-high)", and finally some of the transfers are related to activities, such as "biànxiàng (变相, disguised)", “chuíqīng (垂青, to appreciate)", “fân'àn (翻案, to reverse the verdict)", “fànmài (贩卖, to sell illegally)", “dăomăi-dăomài (倒买倒卖, to make fraudulent buying and selling)", “pòchăn (破产, to go bankrupt)", "bāobàn (包办, to run the whole show)", "biāoxīn-lìyì (标新立异, to create something new and original)”, “găn’ēn-dàidé (感恩戴德, to be greatly grateful)", “móuhuà (谋划, to plan)”, and “cèhuà (策划, to brew a plot)”. The above four kinds of transfers cover feudalism, capitalism, revisionism and the black, ranging from the feudalist “dìwáng (帝王, emperors)", “guìzú (贵族, noblemen)” to the "háohuá (豪华, luxury)" and "ānlè (安乐, peace)" of the capitalist life, from the petty bourgeois sense of “àiqíng (爱情, love)” to the decadent and degrading "gèrén zhǔyì (个人主义, individualism)" and "qíngrén (情人, lover)". All those are allegedly to be "swept into the historic rubbish bin", therefore, they are undoubtedly derogated terms. (Diao Yanbin, 2006:189, 190)

Similar changes are also reflected in the word "xiào (孝, filial piety)". In a survey by Li 
Haixia (2005), "xiào" has a commendatory purity value of 9.6 (10 is the full pure value), the highest value of 50 selected entries and it has a strongly commendatory sense. However, dictionaries show the changes of "xiào" in commendatory and derogatory senses at different times. The following explanations are adopted by Guo Xi (2004:121) from different versions of the Xinhua Dictionary (a Chinese dictionary):

【1】 To respect parents as a child. (1962)

【2】 One feudalist ethics and morality, to support and be filial to parents. (1971)

【3】 Confucian reactionary preaching (1980)

【4】 In old days, to be completely filial to parents; in modern times, to respect and support parents. (1990)

【5】 To respect and support parents. (2004)

"Xiào" was frequently used then to build compound words, which are without exception derogatory, such as “xiàozǐ-xiánsūn (孝子贤孙, a filial son and good grandson)".

Some other idioms originally with neutral emotive overtones were also derogated, such as “gănjī-tìlíng (感激涕零, to shed grateful tears)", “ànsòng-qiūbō (暗送秋波, to cast flirtatious looks at somebody)”, “àndù-chéncāng (暗度陈仓, to do one thing under cover of another)", “shàfèi-kǔxīn (繁费苦心, to make painstaking efforts)", “shàyǒu-jièshì (繁有介 事, to pretend to be serious)", “mòshǒu-chéngguī (墨守成规, to move in a groove)", "dúshàn-qíshēn (独善其身, to preserve one's own purity and integrity and pay no attention to others)", “xiāoyáo-zìzài (逍遥自在, be carefree and enjoy life)"; some originally commendatory terms tended to be derogated or were derogated, such as "găn'ēn-dàidé" (感 恩戴德, to be deeply grateful), "huòzhēn-jiàshí (货真价实, the genuine goods at fair prices)", “shùbēi-lìzhuàn (树碑立传, to glorify somebody by singing his praises)", “gēgōng-sòngdé (歌功颂德, to sing the praises of somebody)", “wēnqíng-mòmò (温情脉 脉, to be full of tender affection for somebody)", “yīběn-zhèngjīng (一本正经, in a serious manner)", “dàcí-dàbēi (大慈大悲, to be infinitely merciful)", “ȳ̄guān-chǔchǔ (衣冠楚楚, to be immaculately dressed)”, “ānfèn-shǒujǐ (安分守已, to be content with one's lot)”, “xiánqíng-yìzhì (闲情逸致, to be in a leisurely and carefree mood)", "shénhū-qíshén (神乎 其神, to be miraculous)", “zhèngrén-jūnzǐ (正人君子, a just and upright man)”.

(b) A large number of newly coined derogatory terms appeared. During the Cultural Revolution derogatory terms took a high proportion of newly coined words. For instance, 39 derogatory words of the 141 entries which were in fashion in 1967 are collected in The Contemporary Dictionary of China's Fashionable Language, compiled chronically by Xiong Zhongwu (1992), and they take 27.7 percent, among which is a high proportion of 
derogatory terms such as “xiăo páchóng (小爬虫, small reptile)" and words like that. And during the Cultural Revolution some of them were even coined with labels such as "hei jùdiăn (黑据点, black stronghold)", “hēi sīlìngbù (黑司令部, black military command)", "hēi Xiūyăng (黑《修养》, black Self-Refinement, name of a book)", "hēi zŭzhī (黑组织, illegal organization)" and others of the "hēi (黑, Black)" series, up to almost 40 derogatory entries of the frequently used popular terms then (Zhou Jian \& Li Genxiao, 1998).

(c) The already existing derogatory terms also had an increase in the frequency of their uses, which is considered to be related to their widened scope of applications. Refer to Tables 1 to 3 for their increased frequency of uses. Another example is in critical essays, the descriptive and commentary adverbs before verbs which are mostly derogatory words, such as “jíduān kuángwàng de gōngjī (极端狂妄地攻击, to ultra-wantonly attack)", “jiăohuáde xiànzhì (狡猾地限制, to craftily restrict)”. (Note: In Chinese, when used to modify verbs adverbs usually go before verbs.)

After an investigation into the uses of the derogatory terms in different periods and in different stages in the history of Chinese language, it is found that the period of the Cultural Revolution is one in which derogatory terms were used most widely and most frequently. However, contrary to the large-scale uses of derogatory terms, some of them were employed in a narrowed scope and less frequently. They are the derogatory terms which were not elevated politically during the Cultural Revolution. (Diao Yanbin, 2007)

The trend of derogation rose against the background of sharp political polarization. While many commendatory terms were used in a narrowed scope and less frequently, and shifted in the direction of derogation, i.e. the negative growth of the commendatory terms, some commendatory entries, which could be used to praise the people and the objects relevant to "gémìng (革命, revolution)", e.g. "gémìng linngxiù (革命领袖, revolutionary leader)”, “gémìng zǔzhī (革命组织, revolutionary organization)”, "gémìng qúnzhòng (革 命群众, revolutionary masses)”, “gémìng shìyè (革命事业, revolutionary cause)”, “gémìng xíngshì (革命形势, revolutionary situation)” and “wéngé yùndòng (文革运动, revolutionary cultural movement)", had a positive growth, resulting in a wider scope and higher frequency. Such an antithesis can be clearly and universally noticed, in the positively growing entries and the negative ones. Five antithetical pairs from the People's Daily from different years are listed here to show their frequency; they are examples of the positive growth terms: “fềngshuò (丰硕, fruitful, plentiful and substantial)”, “gāo'áng (高 昂, in high spirits, or hold one's spirit high)", “gémìng (革命, revolution)", “háomài (豪迈, bold and generous)", "ziháo (自豪, be proud)", and those of the negative growth terms: 
“fêngmăn (丰满, full and round, well-developed)”, “gāomíng (高明, wise)”, “géxīn (革新, innovation)”, “háoshuăng (豪爽, straight-forward)”, “zì’ài (自爱, self-respect)”.

Table 4 Statistics of the positive and negative growth of the commendatory terms

\begin{tabular}{|c|c|c|c|c|c|}
\hline year & $\begin{array}{l}\text { fēngshuò fēngmăn } \\
\text { (丰硕) } \\
\text { (丰满) }\end{array}$ & $\begin{array}{l}\text { gāo'áng gāomíng } \\
\begin{array}{l}\text { (高昂) } \\
\text { (高明) }\end{array}\end{array}$ & $\begin{array}{l}\text { gémìng géxīn } \\
\text { (革命) (革新) }\end{array}$ & 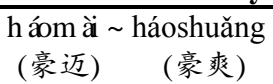 & $\begin{array}{l}\text { zìháo zì'ài } \\
\text { (自豪) (自爱) }\end{array}$ \\
\hline 1957 & $28---52$ & 37 ---- 112 & 3164---133 & 73 ---- 11 & $175--10$ \\
\hline 1967 & 69 -----5 & 80 ---- 36 & 6658---67 & 101 ---- 0 & 167 ---- 4 \\
\hline 1977 & 94 ---- 14 & 73 ---- 24 & $4851---333$ & $127---2$ & 111 ---- 0 \\
\hline 1987 & 84 ---- 50 & 60 ---- 62 & 1733---202 & $22---23$ & 82 ---- 23 \\
\hline
\end{tabular}

In spite of the polarization, cruel struggle and merciless attack were the theme of the Cultural Revolution, and the derogation was thus still the main trend of the language of this period.

\section{The second large-scale transfer}

In the new era of Opening to the Outside, the Modern Chinese language experienced the second large-scale transfer in its word emotive overtones. As against its derogation in the first large-scale transfer, the second one features "de-derogation", which is reflected in the following five aspects:

(a) A thorough correction of derogation in the first large-scale transfer brings a large number of terms back into their original emotive overtones. The above discussed "Xiào ( to be filial)", for instance, resumes its totally commendatory sense regardless of whether it is used as a single word or to form a compound; "qitú (企图, attempt)", as another instance, begins to carry some neutral senses, though it is mostly used in derogatory senses. Moreover, other terms such as "dì (帝, Emperor)", “huáng (皇, Emperor)", “Wáng (王, King)", "bà (霸, tyrant)", all of which were used derogatorily as a single word or a morpheme during the Cultural Revolution, have become frequently-used commendatory words or morphemes, for example, “yǐngdì (影帝, best actor/actress winner)", “tiàoshuǐ nühuáng (跳水女皇, Queen of diving)”, “sānguànwáng (三冠王, winner of three gold medals in one season)", “chēngbà quántán (称霸拳坛, to dominate the boxing like king)" and so on. Even some other terms have similar changes such as "cèhuà (策划, plan out)", “jítuán (集团, groups)". They were neutral in emotive overtones before the Liberation, derogatory during the Cultural Revolution, but they resume their neutral colors in the new era after the Opening to the Outside policy.

(b) Some existing derogatory terms become commendatory or neutral in their emotive overtones. There are about 20 entries clearly labeled "derogatory" in A Modern Chinese 
Dictionary, such as “yuánxíng (原形, true colors)", “pǒcè (医测, ulterior motives)", “găitóu-huànmiàn (改头换面, to dish up the same old stuff in a new form)", "gèbié (各别, different, special)”, “gèsè (各色, different, special)”, “guānchăng (官场, officialdom)”, “guànjì (惯技, old tricks)”, “kànfêng-shǐduò (看风使舵, take one's cue from changing conditions)”, “mùhòu (幕后, behind the curtain)”, “chuīgǔshǒu (吹鼓手, advocator of a particular counter-revolutionary theory)”, “pínáng (皮囊, skin)”, “sā (撒) / shīzhăn (施展) (put to full use)", “shàngcuàn-xiàtiào (上宲下跳, run clandestine errands)", “shùnmín (顺 民, square John)”, “sǐdăng (死党, diehard followers)”, “sǐ lǎohǔ(死老虎, dead tiger)”, “wéi-suǒyùwéi (为所欲为, do or act as one wishes or pleases)", “xìngchén (幸臣, favorite man)", “xiōngxiōng (汹汹, in a menacing way)", “páozhì (炮制, concoct)”, etc. (Xie Haihong \& Zhang Zhiyi, 2003). Of the 20 entries, except some dialacts, adhesive words and some rarely used terms such as "gèbié (各别, different, special)", "gèsè (各色, different, special)", “pǒcè (医测, ulterior motives)", “xiōngxiōng (汹汹, in a menacing way)”, “pínáng (皮囊, skin)”, “sā (撒, put to full use)”, “shùnmín (顺民, square John)”, “sǐ lăohŭ (死老虎, dead tiger)”, “xìngchén (幸臣, favorite man)”, the others such as “yuánxíng (原形, true colors)", “găitóu-huànmiàn (改头换面, to dish up the same old stuff in a new form)”, “guānchăng (官场, officialdom)”, "kànfēng-shǐduò (看风使舵, take one's cue from changing conditions)”, “mùhòu (幕后, behind the curtain)”, “chuīgǔshǒu (吹鼓手, advocator of a particular counter-revolutionary theory)", “shàngcuàn-xiàtiào (上察下跳, run around on sinister errands)", “wéi-suǒyùwéi (为所欲为, do or act as one wishes or pleases)", and "páozhì (炮制, concoct)" have changed their emotive overtones in modern times from derogatory to neutral to different extents, and "yuánxíng (原形, true colors)", "găitóu-huànmiàn (改头换面, to dish up the same old stuff in a new form)", and "mùhòu (幕后, behind the curtain)” are used more in neutral emotive overtones.

In some popular or very special writings, some derogatory language used to describe demons, monsters and objects of the sort become neutral and some even tend to be commendatory, and such usage shows an increasing tendency. Of the derogatory entries used to describe demons or monsters, “(lăo) yāojīng ((老)妖精, old leprechaun)” is used to denote an experienced person or a veteran; "húlijīng (狐狸精, a foxtrel)" is used to describe a good-looking and charming female. There are other derogatory terms or morphemes describing the evil but wise people like "húlijīng (狐狸精, a foxtrel)", such as “láng (狼, wolf)”, “fēnggǒu (疯狗, a mad dog)”, “-chóng ( 虫(网虫, 书虫), -worm / insect (e.g. net-bug, book-worm)”. Zhu Guanghu, Coach of China's National Football Team, suggested “fēnggǒu jīngshén (疯狗精神, the spirit of mad dogs)" in the Chinese year of the 
Dog as the Soul of the Team. His coined phrase is so fresh that such a style of compounding spreads like fire, and frequently appears in newspapers. They are hardly conveying any derogatory senses, thus a team or a team member carrying out such a spirit is called a “fēnggǒu (疯狗, mad dog)". With “fênggǒu jīngshén (疯狗精神, the spirit of mad dogs)", many new related compounds appear, but none of them has a derogatory sense, e.g. “fênggǒu zúqiú (疯狗足球, mad-dog football)", “fênggǒu zhànfã (疯狗战法, mad-dog way)", “fēnggǒu dăfã (疯狗打法, mad-dog play)", “fēnggǒu zhànshù (疯狗战术, mad-dog tactics)", “fênggǒu guózú (疯狗国足, mad-dog national team)”, “fênggǒu qiúduì (疯狗球 队, mad-dog football team)", and “fēnggǒu jūn (疯狗军, mad-dog army)". And the same is true of other new compounds, such as "fềnggǒu zhèn (疯狗阵, mad-dog formation)", “fênggǒu xíng (疯狗型, mad-dog type)", “fēnggǒu shì (疯狗式, mad-dog mode)”.

(c) Many existing derogatory terms realize their emotive color transfers in their new senses, which is an attractive phenomenon even at present. A typical example is the word "shăguā (俊瓜, a fool)", which used to be a word to curse somebody. However, it now means "(of something) that can be conveniently handled or operated" (Wang Junxi, 2003) or "easy to use", "easy to understand". It is at least neutralized, and therefore is used to form compounds, e.g. "shăguā xiàngjī (俊瓜相机, a point and shoot camera)", "shăguā xǐyījī (傻瓜洗衣机, an automatic or easy-to-operate washing machine)", "shăguā diànnăo (傻瓜电脑, an easy-to-operate computer)". Similar transfers like this in the word "shăguā (偼瓜, a fool)" also happen to “lănhàn (懒汉, a lazy dog)", “móguǐ (魔鬼, a devil)” and so on. (Zuo Linxia, 2004:35)

(d) There are very few newly-coined derogatory terms. So far in the new era, although there is a rapid growth of newly-coined terms, in that large number newly-coined derogatory terms take a very small proportion. Lin Lunlun and other scholars (2000) collected 1800 new terms, among which there were 68 derogatory ones, approximately $3.8 \%$ of the total. Compared with $27.7 \%$ popular derogatory words in 1967 , as discussed above, there is a great decline. For newly coined derogatory words, their senses come more from the entailed ugliness of the denotata (e.g. "sānpéi (三陪, the girl who provides illegal sexual service, esp. prostitute)”, “chī ná kā yào (吃拿卡要, to eat, take, block and to racketeer)", "bāo èrnăi (包二奶, to keep a concubine)", "bàng dàkuăn (傍大款, to be a concubine to a rich man)", than from the subjective comments based on "revolutionary" thoughts and ideals in an earlier stage (like "hēi jùdiăn (黑据点, black stronghold)", “sǐ lăohǔ (死老虎, dead tiger)", “lāo dàocăo (捞稻草, to catch a straw, means to make full advantage of enemy's or opponent's minor mistake(s) to change his/her doomed fate)", 
“xiăo páchóng (小爬虫, small reptile)”, etc.

(e) Once excessively-ranged and over-frequently used, derogatory terms have been narrowed and lowered considerably. This can be obviously inferred from the following table on the occurrences and frequencies of the four derogatory terms which are sampled from our period-based corpus (6 million Chinese characters in total, covering different styles of writings). (More details about the Corpus are covered by Diao Yanbin, 2004:139-141)

\begin{tabular}{|c|c|c|c|c|c|c|}
\hline \multirow[t]{2}{*}{ Terms } & \multicolumn{2}{|c|}{ Before the Liberation } & \multicolumn{2}{|c|}{$\begin{array}{c}\text { During the Cultural } \\
\text { Revolution }\end{array}$} & \multicolumn{2}{|c|}{$\begin{array}{l}\text { After the Cultural } \\
\text { Revolution }\end{array}$} \\
\hline & samples & frequency & samples & frequency & samples & frequency \\
\hline $\begin{array}{l}\text { Chìluǒluǒ } \\
\text { (赤裸裸, naked) }\end{array}$ & 4 & 0.0000027 & 9 & 0.0000075 & 6 & 0.0000043 \\
\hline $\begin{array}{l}\text { biéyǒu-yòngxīn } \\
\text { (别有用心, ulterior) }\end{array}$ & 0 & 0 & 18 & 0.0000113 & 3 & 0.0000022 \\
\hline $\begin{array}{l}\text { sàngxīn-bìngkuáng } \\
\text { (丧心病狂, unscrupulous) }\end{array}$ & 0 & 0 & 2 & 0.0000013 & 1 & 0.0000007 \\
\hline $\begin{array}{l}\text { xiēsī-ď̌lı̌ } \\
\text { (歇斯底里, hysterical) }\end{array}$ & 0 & 0 & 4 & 0.0000025 & 2 & 0.0000013 \\
\hline
\end{tabular}

(f) The new derogatory terms coming into existence during the Cultural Revolution, like “xiăo páchóng (小爬虫, small reptile)", "hēi jùdiăn (黑据点, black stronghold)", "hēi sīlìngbù (黑司令部, black military command)” and so on, are not in use anymore.

\section{The reasons for the large-scale transfers of word emotive overtones}

Xie Haihong \& Zhang Zhiyi (2003) suggested that "social life has imposed such a great impact on the transfers of language emotive overtones that when a society experiences an abrupt change, values and moral standards change substantially as well, making many words' emotive overtones change significantly". This is squarely proved by the two large-scale transfers of commendatory and derogatory emotive overtones in Modern Chinese language.

To sum up in a word the main features of the times in which the two big transfers happened, "dòuzhēng (斗争, struggle)" is the only right word to cover the period from the foundation of the Communist Party of China to the Cultural Revolution. The slogan during the Cultural Revolution was "class struggle is the very centre", and the purpose of struggle was of course to "break up the old and build up the new". With such a thought and mindset, 
people intended to re-examine and re-judge the reach-me-downs and old thoughts and ideology. As a consequence, many were labeled "feudalism, capitalism and revisionism", and emotive overtones were imperatively transferred from the commendatory to the derogatory. Meanwhile, some love-or-hate terms were happily coined and used, even in an increasingly great expansion of their scopes. The Cultural Revolution is the period in which derogatory terms were used in the greatest number, scopes and with the highest frequency in the history of Chinese language development.

The most important reason for the second of the two great transfers is closely related to socioeconomic development and the Opening to the Outside policy. It is the product of changes in social life and values. Mainland China, in which the second great transfers happened, was a pluralistic society where "economic development is the core" and commercial mentality was strongly held, money worship, individualism and vulgar culture were booming. Only with this notion and mindset could people change their thoughts of class struggle, as discussed above, and resume the order from chaos caused by class struggle, and rise with a relatively more placid state of mind than that of "class struggle". This mindset alone could support the social commercialization. Some commendatory and derogatory comments, once distorted, were finally restored. Some conventionally derogatory language was also used more neutrally. Among the newly-coined terms were few derogatory words subjectively dominated. Therefore, the new era dating from 1978 has been a period during which derogatory terms were used in the smallest number, the least wide scopes and with the lowest frequency. For example, the change in the sense of the term “xiăojiě (小姐, Miss, or young lady)" reflects not only the changes of social economic ties, but also the changes of the social climate. It is the change in people's cognitive psyche reflected in language, and it stands as a "rearview mirror" of language use and cognitive psyche, and meanwhile as a living fossil of the social changes (Hu Fanzhu \& Fan Xiaoling, 2007; Guo Duling, 2005).

With the influence of vulgar culture, de-derogation of derogatory terms is looked on as an efficient way in our present language uses to demonstrate the new initiatives. In this respect, trademark wording is the most typical of this trend. Traditional trademark wording greatly emphasized good association so as to stimulate purchases, so commendatory terms or morphemes were used more. However, it seems not to be the case today. Wordings of a large quantity of local name brands like "jiǔguǐ (酒鬼, Drunkard, a brand of liquor)", "xiăo hútu (小糊涂, Little Drunkard, a brand of liquor)", “xiāngbalăo (乡巴佬, Jaap, a brand of halogen ready food)", "shăzi (件子, Fool, a brand of melon seeds)", "bèndàn (笨蛋, Stupid, 
a brand of eggs)", “Wáng Pó (王婆, Mother Wang, a brand of water melon)" and so on (Wu Hanjiang, 2005:35) are "making every effort to advertise their individualized features", a social psychology which is another reason for the transfers of emotive overtones. (Sheng Yinhua, 2002)

With the shift of social attention, the approach of word associative meanings has changed (Ma Qinghua, 2000:202-224), which also casts a good impact on the changes of emotive overtones. As is known to all, many senses of a word, the sememes of each sense, the semantemes of a compound word and features of a word joined by others all shape its associative meanings. Take the sememes as an example, “(huáng)dì ((皇)帝, Emperor)” has the sememes [+male], [+feudalist age], [+within (a state)], [+supreme] and [+in power]. During the first great transfers, “dì (帝, Emperor)” in “dì wáng jiàng xiàng (帝王将相, Emperor, Commander, and Prime Minister)" is mainly associated with sememes such as [+feudalist age] and [+in power] (so, he is an [+exploiter] and [+oppressor]), it was derogatory. During the second transfers, “dì (帝, Emperor)" in “yǐngdì (影帝, outstanding movie star)" is associated with sememes such as [+within (a state)], [+supreme] and [+in power]. “yinng (影, movie)" was used as a component so as to change its application scope, and it became commendatory.

One more reason for the second great transfers comes from much exposure to foreign languages in the economy reform and international exchanges. For example, "huāhuā-gōngzǐ (花花公子, playboy)", a literal translation from a foreign name brand of Playboy, means in Chinese "a child born to a rich family who never attends to his proper duty or business but loves foods, drinks, play and merriness" (Ref. The Contemporary Chinese Dictionary, the Commercial Press, 2005), and its English meaning can be easily derived from the introduction on a home page of the Playboy's corporate agent. It says, "The name brand Playboy was created in 1953 by an American called Hugh M. Hefner. Playboy can be paraphrased as fashion, elegance and happiness, implying a style of being 'fashionable and young forever"'. Although the Chinese "huāhuā-gōngzì" means nothing of the English Playboy, it gives the derogatory "huāhuā-gōngzî" a non-derogatory emotive color after its entry into China.

The transfers of emotive overtone in the word "fēngkuáng (疯狂, crazy)" is another example. The term itself is derogatory, and now it is partially used as a neutral term and in quite high frequency. Surfing the Internet brings a lot of its compound words into our eyes, such as “fēngkuáng yīngyǔ (疯狂英语, crazy English)", “fềngkuáng xiànchăng (疯狂现场, crazy scene)", “fēngkuáng lùntán (疯狂论坛, crazy forum)", “fēngkuáng xuéxí wăng (疯狂 
学习网, crazy learning website)”, “feengkuáng gòuwù (疯狂购物, shopping crazily)”, “fēngkuáng xiàzăi (疯狂下载, to download crazily)" and “fēngkuáng liáobā (疯狂聊吧, crazy chat-room)". This phenomenon rise is due to the influence of English and classroom English in China. The Chinese "fēngkuáng (疯狂)" means “crazy” or “crazily” in English. "Crazy" is a polyseme and its emotive overtone is not a monotone. Its senses are "ill in the mind, mad; impractical, foolish; wildly excited, very fond (of) or interested (in); wildly and/or very actively" and so on (Ref. The Longman English-English and English-Chinese Dictionary, the Foreign Language Teaching and Research Press, 1992). We can often see its compound words which are not derogatory, such as:

crazy golf game/crazy talk/crazy river/crazy news/crazy old reader

swim crazily/dance crazily/work crazily/crazily in love/crazily beautiful

"Li Yang’s 'fēngkuáng yīngyǔ (疯狂英语)”, once a popular English teaching pedagogy in China, is given the equivalence "crazily speak English" in English. The transfer of emotive overtones in the Chinese "fēngkuáng (疯狂)" is closely and intrinsically linked to this occurrence.

Nowadays, "móguǐ (魔鬼, devil or ghost)" is often used to express "paranormally (good), unusually" or "severe, strict". Some compounds with it in the former sense are as follows: “móguǐ shēnduàn (魔鬼身段, paranormally good body shape)”, “móguǐ nŭláng (魔鬼女郎, unusually charming lady/girl)”, “móguǐ bān de gēhóu (魔鬼般的歌喉, unusually beautiful voice)", “móguǐ bān de yīnyuè lịjiě (魔鬼般的音乐理解, unusually good ear for music)”, “móguǐ zhǔchăng (魔鬼主场, paranormal home field)”, “móguǐ biānduì(魔鬼编队, unusually good team formation)”, “móguǐ bān de chéngjì (魔鬼般的成绩, paranormally exciting achievement)", “móguǐ duixíng (魔鬼队形, unusually good team formation)”, “móguǐ měitún (魔鬼美慰, unusually callipygian)” and so on. Some compounds with "móguǐ”" in the latter sense are "móguǐ jiàoliàn (魔鬼教练, extremely strict coach)", "xiàng móguǐ yīyàng nǔlì (像魔鬼一样努力, make severe efforts to do sth.)”, “móguǐ jiànshēn jìhuà (魔鬼健身计划, excessively strict body-building plan)”, “móguĭ dà kăoyàn (魔鬼大 考验, an extremely severe test)", “móguǐ shìde tiăozhàn sài (魔鬼式的挑战赛, an unusually hard challenge match)", “móguǐ xùnliàn (魔鬼训练, excessive strict training)”, “móguǐ sàichéng (魔鬼赛程, an unprecedented hard schedule)" and "móguǐ jiănféi (魔鬼 减肥, a too strict weight-loss plan)”. Such a transfer style in emotive overtones and usage might have been borrowed from our neighbor Japan. As we can see in Japanese, "guǐ (鬼)/ móguǐ (魔鬼)” has many different meanings, one of which means an imaginary monster, a concept influenced by Buddhism. For example, there are "èguǐ (饿鬼, ghoul)", green ghost 
and red ghost in hell, which turn into usually beautiful girls and men and appear in human's world. Besides, it also means a person like a ghost, referring to a man of great intrepidity or valor or one who is extremely cold-hearted (e.g. "tăozhàiguǐ (讨债鬼, a cold-hearted dunner)", or referring to the degree of one's determination, concentration or attention on some business (e.g. "gōngzuò guǐ (工作鬼, a workaholic)"). If "guľ (鬼)" is used as a prefix to a noun, it means valor, cold, abnormity and massiveness, such as "guǐ wǔzhě (鬼 武者, a valor and cold Kongfu bearer)” and “guǐpó (鬼婆, abnormal lady)”. (Liu Yuanman, 2003:145)

How the transfer of Chinese language emotive overtones is impacted by the Chinese localization of loaned terms and their influence on Chinese language has not been discussed. A lot can be done in this respect.

\section{References}

A Modern Chinese Dictionary. 2005. [Z] The Commercial Press.

Diao Yanbin. 2004. An Introduction to the Delexical Verb of Modern Chinese. [M] Dalian: Liaoning Normal University Press.

Diao Yanbin. 2006. History of Modern Chinese Language. [M] Fuzhou: Fujian People's Press.

Diao Yanbin. 2007. Analysis of the Cultural-Revolutionary Derogatory Terms. [J] Journal of Ningxia University (Humanities \& Social Sciences Edition). No. 1.

Guo Duling. 2005. Review on the Emotional Color Changes in “xiăojiě(小姐)". [J] Modern Chinese. No. 10.

Guo Xi. 2004. Chinese Social Linguistics. [M] Hangzhou: Zhejiang University Press.

Hu Fanzhu \& Fan Xiaoling. 2007. The Usage of “xiăojiě (小姐)” in Contemporary Chinese: Synchronic Differences in Distribution and Possibilities for Diachronic Change. [J] New York: Macrolinguistics. Vol. 1.

Li Haixia. 2005. Shades of Commendatory and Derogatory Words. [J] Language Planning. No. 5.

Lin Lunlun, et al. 2000. A Dictionary of New Words in Modern Chinese, 1978 - 2000. [Z] Guangzhou: Huacheng Publishing House.

Liu Yuanman. 2003. On How Chinese Characters Work in Japanese Culture. [M] Beijing: Bejing University Press.

Longman Dictionary of American English. 1992. [Z] Beijing: Foreign Language Teaching and Research Press.

Ma Qinghua. 2000. Cultural Semantics. [M] Nanchang: Jiangxi People's Press.

Sheng Yinhua. 2002. A Talk on "móguĭ (魔鬼)”. [J] Chinese Teaching and Studies. No. 12.

Wang Junxi. 2003. A Dictionary of New Words in Contemporary Chinese. [Z] Shanghai: Chinese Lexicographical Publishing House.

Wu Hanjiang \& Cao Wei. 2005. Trade-Mark Language. [M]Shanghai: Chinese Lexicographical Publishing House.

Xie Haihong \& Zhang Zhiyi. 2003. A Discussion on the Annotations of Attached Sememes. [J] Lexicographical Studies. No. 6.

Xing Gongwan. 1994. Modern Chinese Language. [M]Tianjin: Nankai University Press.

Xiong Zhongwu. 1992. A Dictionary of Popular Expressions in Contemporary Chinese. [Z] Changchun: Jilin Literature \& History Publishing House.

Yang Ling \& Zhu Yinggui. 2005. A Dictionary of Derogatory Words. [Z] Chengdu: Sichuan Lexicographical Publishing House. 


\section{Diao Yanbin Ye Jiaquan}

Yang Zhenlan. 2003. Research on Dynamic Word Coloring. [M] Ji'nan: Shandong People's Press.

Yuan Yulin. 1987. On How Verbs Determine Commendatory or Derogatory Meaning of their Predicates. [J] Chinese Language Learning. No. 3.

Zhang Zhen'an. 2005. Changes of Word's Emotional Coloring. [J] The Journal of Dezhou University. No. 5.

Zhou Jian \& Li Genxiao. 1998. Odd Language in Troubled Time — A Brief Introduction to the Features of "Cultural Revolutionary" Language. [J] Journal of Xuchang Teachers College (Social Science Edition). No. 1.

Zuo Linxia. 2004. The Lingual-Social Interaction Reflected by Word's Emotional Color Transfers. [J] Theory and Practice. No. 10. 